\title{
UJI PELEPASAN LOGAM KROMIUM (Cr) DAN NIKEL (Ni) BEBERAPA MEREK BRAKET STAINLESS STEEL DALAM CAIRAN SALIVA ARTIFISIAL
}

\author{
${ }^{1}$ Chealsea J. Siwy \\ ${ }^{2}$ Lydia E. N. Tendean \\ ${ }^{3}$ P. S. Anindita
${ }^{1}$ Kandidat Skripsi Program Studi kedokteran Gigi Fakultas Kedokteran
${ }^{2}$ Bagian Biologi Fakultas Kedokteran
${ }^{3}$ Program Studi Kedokteran Gigi Fakultas Kedokteran
Universitas Sam Ratulangi Manado
Email: chealsea_jessica@yahoo.co.id

\begin{abstract}
Stainless steel bracket, a popular fixed orthodontic appliance containing chromium and nickel, is used most frequently in fixed orthodontic treatment. Stainless steel bracket interacts with oral cavity environment and causes metal corrosion process. The released chromium and nickel due to the corrosion process can get into the body and cause hypersensitivity reactions. This study aimed to determine the release of chromium and nickel from stainless steel bracket in artificial saliva. This was an experimental laboratory study with a quasy experimental and nonequivalent control group design. Samples were analyzed by using spectrophotometry ultraviolet visible (UV-Vis) to determine the releasing of chromium and nickel. There were 4 kinds of stainless steel bracket immersed and stored in artifisial saliva at $37^{\circ} \mathrm{C}$ for 30 days. The result showed that each sample varied in the release of chromium and nickel from stainless steel brackets in the artificial saliva. Sample A had 0.025 ppm chromium and $0.689 \mathrm{ppm}$ nickel; sample B had $0.002 \mathrm{ppm}$ chromium and $1.012 \mathrm{ppm}$ nickel; sample C had 0.008 ppm chromium and 1.130 ppm nickel; and sample D had 0.027 ppm chromium and $1.176 \mathrm{ppm}$ nickel. The release of nickel of each sample was higher than of chromium. There was no specific pattern of the release of chromium and nickel due to the different composition of stainless steel brackets which depend on the manufacturers.
\end{abstract}

Keywords: stainless steel bracket, chromium, nickel, spectrophotometry UV-Vis, artificial saliva

\begin{abstract}
Abstrak: Braket stainless steel sering digunakan dalam perawatan ortodonti cekat yang umumnya mengandung kromium dan nikel. Braket stainless steel akan berinteraksi dengan lingkungan dalam rongga mulut sehingga menyebabkan proses korosi. Pada proses korosi terjadi pelepasan logam kromium dan nikel yang dapat masuk ke dalam tubuh dan dapat mengakibatkan reaksi hipersensitivitas. Penelitian ini bertujuan untuk mengetahui besarnya logam kromium dan nikel yang terlepas dari braket stainless steel dalam cairan saliva artifisial. Penelitian ini menggunakan metode eksperimental laboratorik dengan jenis penelitian pra eksperimental serta desain penelitian nonequivalent control group design. Sampel diuji menggunakan spektrofotometri UV-Vis untuk mengetahui pelepasan logam kromium dan nikel. Sampel terdiri dari 4 macam merek braket direndam dalam larutan saliva artifisial selama 30 hari pada suhu $37^{\circ} \mathrm{C}$. Data hasil penelitian diolah menggunakan komputerisasi. Hasil penelitian menunjukkan terdapat pelepasan logam kromium dan nikel dalam saliva artifisial yang bervariasi di tiap sampel. Sampel A memiliki pelepasan kromium 0,025 ppm dan nikel 0,689 ppm; sampel B memiliki pelepasan kromium 0,002 ppm dan nikel 1,012 ppm; sampel C memiliki pelepasan kromium 0,008 ppm dan nikel 1,130 ppm; dan
\end{abstract}


sampel D memiliki pelepasan kromium 0,027 ppm dan nikel 1,176 ppm. Pelepasan nikel pada tiap sampel lebih tinggi dibandingkan dengan pelepasan kromium. Hasil penelitian tidak menunjukan pola tertentu, hal ini dapat disebabkan karena komposisi yang berbeda-beda dari braket stainless steel tergantung ketentuan masing-masing pabrik pembuatnya.

Kata kunci: braket stainless steel, kromium dan nikel, spektrofotometri UV-Vis, saliva artifisial

Braket merupakan salah satu komponen utama dalam perawatan ortodonti cekat. Fungsi braket untuk menghantarkan gaya yang diperlukan pada gigi, sehingga braket yang digunakan harus diproduksi dengan akurat, baik dari segi bentuk, tingkat kekuatan serta biokompabilitas. ${ }^{1-3}$

Braket ortodonti yang banyak digunakan terbuat dari logam stainless steel yang umumnya memiliki kandungan kromium (Cr) dan nikel (Ni).Braket logam stainless steel yang dipasangkan pada gigi pasien kurang lebih selama 1-2 tahun akan berinteraksi dengan keadaan lingkungan di dalam rongga mulut yang berpotensi meningkatkan terjadinya korosi logam stainless steel. Pada proses korosi braket stainless steel di dalam rongga mulut, terjadi pelepasan logam kromium dan nikel yang dapat masuk ke dalam tubuh serta menimbulkan beberapa efek seperti, karsinogenik, alergenik, mutagenik dan sitotoksik. ${ }^{1,3-5}$

Penelitian sebelumnya dilakukan oleh Aryani ${ }^{1}$ secara in vitro menunjukan adanya perbedaan lepasan logam kromium dan nikel pada kelompok braket stainless steel yang direndam dalam saliva artifisial selama 30 hari serta masih dalam batas aman untuk tubuh. Berbeda dengan penelitian secara in vivo yang dilakukan oleh Faccioni et $a l^{6}$ dan Minano et $a l^{7}$ menyatakan bahwa konsentrasi yang non toksik sekalipun tetap dapat memengaruhi aspek biologi sel serta memicu kerusakan DNA dari sel mukosa mulut. Di Indonesia beredar berbagai macam merek braket logam stainless steel yang berasal dari mancanegara dengan harga yang beragam. Tidak semua dari merek braket stainless steel yang masuk ke Indonesia menyertakan kandungan jenis logam yang ada pada braket dan tidak semua juga teruji toksisitasnya terhadap tubuh. Pemerintah Indonesia sendiri tidak memiliki sistem pengujian terhadap braket yang diimpor dari luar negeri. ${ }^{1}$

Banyaknya merek braket yang dijual dengan harga yang murah menyebabkan masyarakat cenderung memilih untuk membeli braket sendiri dan dipasangkan oleh tenaga yang bukan berprofesi sebagai dokter gigi atau spesialis ortodonti. Masyarakat hanya dipengaruhi oleh tawaran harga yang murah tanpa mempertimbangkan kualitas serta pengaruhnya bagi kesehatan.

Berdasarkan hal tersebut di atas maka penulis terdorong untuk melakukan penelitian mengenai uji pelepasan logam kromium (Cr) dan nikel (Ni) beberapa merek braket stainless steel dalam cairan saliva artifisial yang beredar di Indonesia.

\section{BAHAN DAN METODE PENELITIAN}

Jenis penelitian yang digunakan yakni eksperimental laboratorik dengan rancangan pra eksperimental. Desain penelitian yang digunakan nonequivalent control group design. Penelitian ini berlangsung dari bulan Februari sampai dengan September 2015 dan dilaksanakan di dua tempat. Pertama, Laboratorium Farmasi Fakultas MIPA Unsrat Manado, yakni melakukan perendaman braket dalam saliva artifisial selama satu bulan pada bulan Juli sampai Agustus 2015. Kedua, Laboratorium Biokimia Jurusan Gizi Politeknik Kesehatan Kemenkes Manado, yakni melakukan pengukuran lepasan logam kromium dan nikel dalam saliva artifisial menggunakan spektroskopi UVVis pada bulan September 2015. Bahan yang digunakan yakni saliva artifisial metode Afnor, braket stainless steel merek PM (China), OS (USA), HS (China), dan 
GX (China). Pengukuran pelepasan logam kromium dan nikel dengan menggunakan alat ukur spektroskopi Ultraviolet-Visible (UV-Vis).Variabel bebas dalam penelitian ini yakni saliva artifisial dan variabel terikat yakni logam kromium dan nikel yang terlepas dari braket stainless steel.

\section{HASIL PENELITIAN DAN BAHASAN}

Hasil pengukuran pelepasan logam kromium dalam saliva artifisial pasca perendaman selama 30 hari menunjukkan terdapat pelepasan logam kromium yang bervariasi pada masing-masing sampel braket. Logam kromium yang terdapat dalam saliva artifisial pada sampel B dan C lebih sedikit dibandingkan sampel A dan D yakni 0,002 ppm dan 0,008 ppm. Logam kromium yang terdapat dalam saliva artifisial pada sampel A dan D lebih banyak yakni 0,0025 ppm dan 0,027 ppm (Tabel 1).

Tabel 1. Hasil pengukuran pelepasan logam kromium pada sampel A, B, C dan D pasca perendaman

\begin{tabular}{cc}
\hline Sampel & $\begin{array}{c}\text { Jumlah Cr dalam saliva } \\
(\mathrm{ppm})\end{array}$ \\
\hline $\mathrm{A}$ & 0,025 \\
$\mathrm{~B}$ & 0,002 \\
$\mathrm{C}$ & 0,008 \\
$\mathrm{D}$ & 0,027 \\
\hline
\end{tabular}

Tabel 2. Hasil pengukuran pelepasan logam nikel pada sampel A, B, C dan D pasca perendaman

\begin{tabular}{cc}
\hline Sampel & $\begin{array}{c}\text { Jumlah Ni dalam saliva } \\
(\mathrm{ppm})\end{array}$ \\
\hline $\mathrm{A}$ & 0,689 \\
$\mathrm{~B}$ & 1,012 \\
$\mathrm{C}$ & 1,130 \\
$\mathrm{D}$ & 1,176 \\
\hline
\end{tabular}

Hasil pengukuran pelepasan logam nikel dalam saliva artifisial pasca perendaman selama 30 hari menunjukkan terdapat pelepasan yang bervariasi pada masing-masing sampel braket. Logam nikel yang terdapat dalam saliva artifisial pada sampel A lebih sedikit dibandingkan sampel B, C dan D yakni 0,689 ppm. Logam nikel yang terdapat dalam saliva artifisial pada sampel B, C dan D lebih banyak yakni 1,012 ppm, 1,130 ppm dan 1,176 ppm (Tabel 2).

Berdasarkan Tabel 1 dan 2, sampel D memiliki pelepasan logam kromium dan nikel yang paling banyak dibandingkan sampel lainnya.Sampel D memiliki pelepasan logam kromium sebesar 0,027 ppm dan nikel sebesar 1,176 ppm.

Penelitian ini bertujuan untuk mengetahui besarnya logam kromium dan nikel yang terlepas dari braket stainless steel. Hasil pengukuran menunjukan adanya pelepasan logam kromium (Tabel 1) dan nikel (Tabel 2) yang bervariasi pada keempat sampel braket yang direndam dalam saliva artifisial. Hasil penelitian ini serupa dengan penelitian yang dilakukan oleh Aryani tahun 2012 di Jakarta yang menunjukan terdapat pelepasan logam kromium dan nikel yang bervariasi pada kelima sampel braket yang direndam dalam saliva artifisial. ${ }^{1}$ Menurut penelitian Almeida et al, saliva terdiri dari sebagian besar air, dan sebagian lain adalah komponen anorganik (bikarbonat, fosfat, natrium, kalium, potassium, klorida dan magnesium) dan komponen organik seperti protein yang berupa enzim. Komponen anorganik inilah yang berperan sebagai media elektrolit yang dapat menyebabkan terjadinya pelepasan kromium dan nikel.,

Berdasarkan hasil penelitian, pelepasan logam kromium dan nikel pada masingmasing sampel tidak memiliki perbandingan maupun pola tertentu. Sampel B memiliki pelepasan kromium yang paling sedikit dibandingkan sampel lainnya namun pelepasan nikelnya terbanyak ketiga setelah sampel $\mathrm{D}$ dan sampel C. Sampel A yang memiliki pelepasan nikel paling sedikit dibandingkan sampel lainnya justru memiliki pelepasan kromium terbanyak kedua setelah sampel D. Tabel 1 dan 2 menunjukan pelepasan nikel lebih banyak dibandingkan kromium. Keadaan ini berbeda dengan klasifikasi menurut AISI. AISI mengklasifikasikan 
sebagian besar alat ortodonti yang terbuat dari stainless steel merupakan golongan austenistik tipe 304 SS dengan kandungan 18-20\% kromium, 8-10\% nikel serta sedikit campuran mangan dan silikon, dan kurang dari $0,03 \%$ karbon. ${ }^{2,5}$

Hasil pengukuran menunjukkan pelepasan logam kromium lebih sedikit dibandingkan pelepasan logam nikel.Hal ini dapat disebabkan karena komposisi keempat sampel braket stainless steel mengandung lebih sedikit logam kromium dari pada logam nikel. Nikel dapat menambah kekerasan, ketahanan terhadap panas dan memberikan kelenturan pada kawat. Kromium dapat membentuk protective surface oksida akibat aktivitas oksigen pada permukaan logam yang kemudian membentuk kromium oksida $\left(\mathrm{Cr}_{2} \mathrm{O}_{3}\right)$ yang dapat melindungi logam dibawahnya dari proses korosi. ${ }^{10}$ Hal ini dapat memengaruhi harga dari braket stainless steel yang beredar di pasaran. Harga yang ekonomis kemungkinan disebabkan oleh sedikitnya campuran logam kromium dalam komposisi yang sebenarnya merupakan komponen yang penting dalam sebuah braket stainless steel.

Pelepasan logam kromium dan nikel yang berlebihan dapat memberikan dampak negatif bagi braket itu sendiri karena dapat menyebabkan perubahan dimensi bentuk braket yang berakibat rapuhnya braket tersebut. Pemakaian braket dengan pelepasan kromium dan nikel yang berlebihan dalam jangka waktu yang lama dapat memengaruhi kesehatan tubuh karena termasuk kelompok logam berat yang dapat menyebabkan reaksi hipersensitivitas tipe IV. ${ }^{11}$ Pelepasan logam kromium dan nikel serta dampaknya bagi tubuh masih membutuhkan penelitian lebih lanjut, karena komposisi dan cara pembuatan produk stainless steel khususnya braket stainless steel merupakan rahasia dari masing-masing perusahaan pembuatnya.

\section{SIMPULAN}

Hasil penelitian ini menunjukan adanya pelepasan logam kromium dan nikel pasca perendaman dalam cairan saliva artifisial selama 30 hari dengan $\mathrm{pH}$ 6,8 dan suhu $37^{\circ} \mathrm{C}$ braket stainless steel yang terdiri dari sampel A produk PM (China) dengan pelepasan kromium 0,025 ppm dan nikel 0,689 ppm, sampel B produk OS (USA) dengan pelepasan kromium 0,002 ppm dan nikel 1,012 ppm, sampel C produk HS (China) dengan pelepasan kromium 0,008 ppm dan nikel 1,130 ppm, dan sampel D produk GX (China) dengan pelepasan kromium 0,027 ppm dan nikel 1,176 ppm.

\section{SARAN}

1. Melakukan penelitian secara in vivo untuk melihat pelepasan kromium dan nikel pada saliva pengguna ortodonti cekat.

2. Melakukan penelitian lebih lanjut tentang dampak pemakaian braket stainless steel yang dijual secara bebas terhadap kesehatan.

\section{UCAPAN TERIMA KASIH}

Ucapan terima kasih disampaikan pada Prof. Dr. Fatimawali, MSi, Apt selaku penguji I, drg. Michael A. Leman, M.MedEd selaku penguji II, dan pada semua pihak yang baik secara langsung maupun tidak langsung telah menumbuhkan ide atau gagasan dalam pemikiran penulis sehingga dapat menyelesaikan artikel ini.

\section{DAFTAR PUSTAKA}

1. Aryani I. Perbandingan tingkat ketahanan korosi beberapa braketstainless steel ditinjau dari pelepasan ion $\mathrm{Cr}$ dan $\mathrm{Ni}$ (eksperimental laboratorik). Jakarta: Fakultas Kedokteran Gigi UI; 2012.

2. Oh KT, Choo SU, Kim KM, Kim KN.A stainless steel bracket for orthodontic application. Eur J Orthod. 2005;27:237-44.

3. House K, Sernetz F, Dymock D, Sandy J, Ireland A.Corrosiion of orthodontic appliances-should we care?. Am J Orthod Dentofacial Orthop. 2008;133:584-92.

4. Costa MT, Lenza MA, Gosch CS, Costa I, Dias FR. In vitro evaluation of corrosion and cytotoxicity of orthodontic brackets. J Dent Res 2007;86(5):441-5.

5. Agaoglu G, Arun T, Isgu B, Yarat A. 
Nickel and chromium levels in the saliva and serum of patients with fix orthodontic appliance. Angle Orthod 2001;71(5):375-9.

6. Faccioni F, Franceschetti P, Cerpelloni M, Fracasso ME. In vivo study on metal release from fixed orthodontic appliances and DNA damage in oral mucosa cells. Am J Orthod Dentofacial Orthop 2004;125:24-9.

7. Minano FE, Ortiz C, Vicente A, Calvo JL, Ortiz JA. Metallic ion content and damage to the DNA in oral mucosa cells of children with fixed orthodontic appliances. Biometals 2011;24(5):935-41.

8. Kristianingsih R, Joelijanto R, Praharani
D. Pelepasan ion $\mathrm{Ni}$ dan $\mathrm{Cr}$ kawat ortodontik stainless steel yang direndam dalam minuman berkarbonasi. Jember: Universitas Jember Fakultas Kedokteran Gigi; 2014.

9. Almeida PDV, Gregio AMT, Lima AAS, Azevedo LR. Saliva composition and function: a comprehensive review. The Journal of Contemporary Dental Practice 2005;9(3):1-11.

10.Bardal E. Corrosion and protection. London: Springer-Verlag, 2004.

11.Lu CL. Toksikologi dasar: asas, organ sasaran, dan penilaian resiko. $2^{\text {nd }}$ ed. Jakarta: UI Press; 1995 